\title{
Selective Crystallization of Magnetic Garnet Films on Bragg Mirrors by Laser Annealing
}

\author{
Yuta Suzuki, Taichi Goto, Yu Eto, Hiroyuki Takagi, Pang Boey Lim, Alexander V. Baryshev*, \\ and Mitsuteru Inoue \\ Toyohashi University of Technology, 1-1 Hibarigaoka, Tempaku, Toyohashi, Aichi 441-8580, Japan \\ "Electronics-Inspired Interdisciplinary Research Institute, 1-1 Hibarigaoka, Tempaku, Toyohashi, Aichi 441-8580, Japan
}

\begin{abstract}
One of realization of magnetophotonic crystals (MPCs) has a microcavity structure where a thin magnetic garnet film-bismuth-substituted yttrium iron garnet (Bi:YIG)-is sandwiched between two Bragg mirrors (BMs) made of $\mathrm{Ta}_{2} \mathrm{O}_{5}$ and $\mathrm{SiO}_{2}$. For MPCs fabricated by sputtering, annealing of as-sputtered Bi:YIG films is essential for garnet crystallization. However, $\mathrm{Ta}_{2} \mathrm{O}_{5}$ is also crystalized at garnet crystallization temperatures, when utilizing a conventional annealing in an electric furnace. $\mathrm{Ta}_{2} \mathrm{O}_{5}$ crystallization worsens optical parameters of $\mathrm{BMs}$ and consequently properties of an MPC. To overcome this problem, we selectively annealed as-sputtered Bi:YIG/BM samples by a high power laser. Experiments showed that Bi:YIG can be crystallized while keeping $\mathrm{Ta}_{2} \mathrm{O}_{5}$ in the amorphous state; this was confirmed by the transmission electron microscopy.
\end{abstract}

Keywords: magnetophotonic crystal, laser annealing, Bragg mirror, magneto-optical garnet, spatial light modulator

\section{レーザ熱処理を用いた誘電体ミラー上の磁性ガーネット薄膜の選択的結晶化}

\author{
鈴木祐太・後藤太一・江藤優・高木宏幸・Pang Boey Lim・Alexander V. Baryshev* • 井上光輝 \\ 豊橋技術科学大学, 愛知県豊橋市天伯町雲雀ヶ丘 1-1 （广441-8580） \\ *豊橋技術科学大学, エレクトロニクス先端融合研究所, 愛知県豊橋市天伯町雲雀ヶ丘 1-1 （テ441-8580）
}

\section{1. はじめに}

磁性フォトニック結晶 (Magnetophotonic crystal: MPC)は，可 視光域において大きな磁気光学 (Magneto-optical: MO) 効果と高 い透過率を同時に示すことから, 磁気光学空間光変調器 (Magneto-optical spatial light modulator: MOSLM) 等への応 用が期待されている 1-6). 一般的な MPC は数百ナノメートルの膜 厚の磁性ガーネット薄膜を $\mathrm{Ta}_{2} \mathrm{O}_{5}$ や $\mathrm{SiO}_{2}$ などの屈折率の異なる誘 電体層を交互に積層した誘電体ミラー (Bragg mirror: BM) で挟 んだキャビティ構造をもつ 6-8). 可視光域で大きな $\mathrm{MO}$ 効果をもつ 磁性ガーネット膜としてビスマス置換イットリウム鉄ガーネット

(Bi:YIG）が知られており 9,10), MPCにも Bi:YIG が使われるこ とが多い.このBi:YIG はスパッタ法や有機金属分解法などを用い て形成され，いずれも結晶化する目的で $600 \sim 800{ }^{\circ} \mathrm{C}$ 程度の高温.

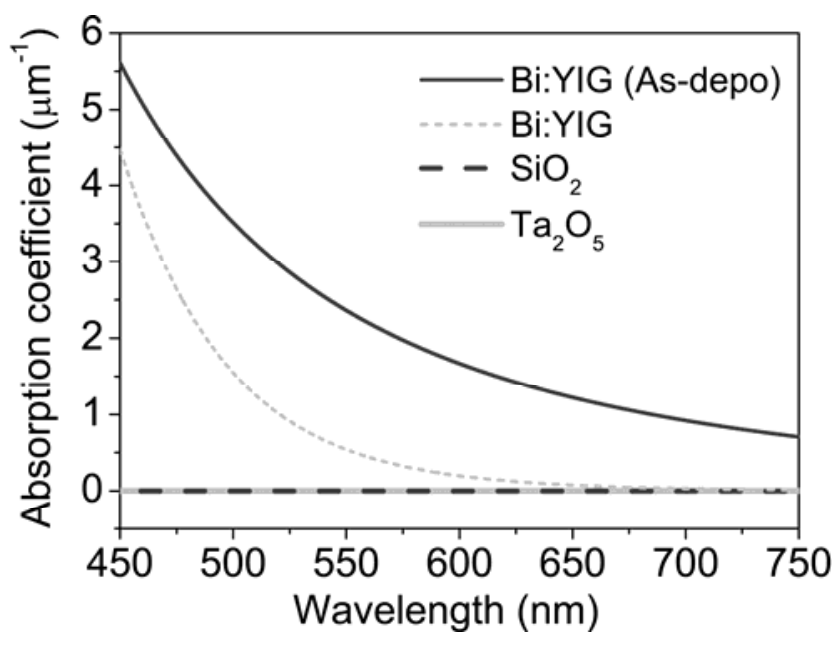

Fig. 1 Absorption coefficient spectra of components in MPCs.

の熱処理を必要としている 11-14). 特に, 電気炉を用いた急速熱処 理法 (以下, 電気炉熱処理という) では, $750{ }^{\circ} \mathrm{C}$ で約 20 分間以 上の熱処理が必要である ${ }^{13,15)}$. しかし, 高温の電気炉熱処理は下 部 $\mathrm{BM}$ 中の $\mathrm{Ta}_{2} \mathrm{O}_{5}$ 層をも結晶化させ, 光散乱を生じることが最近 分かった ${ }^{16)}$. Bi:YIGよりも相対的に薄い $\mathrm{Ta}_{2} \mathrm{O}_{5}$ 層の結晶化の影響 の方が大きい理由は, 詳しくは明らかになっていないが, 結晶化 前後の屈折率変化が大きい為と考えられている. この光散乱は, MPC をMOSLM のような 2 次元画像を表示寸るデバイスのディ スプレイとして使用する際に, 各ピクセル内部での明るさが不均 一になり性能劣化の原因となる. 本研究は, 上述した課題を, レ 一ザを用いた熱処理（以下，レーザ熱処理という）によって解决 したものである.

Figure 1 にMPC を構成する材料の光吸収係数スペクトルを示 す. $\mathrm{Bi}: \mathrm{YIG}$ の波長 $532 \mathrm{~nm}$ における光吸収係数は $\mathrm{Ta}_{2} \mathrm{O}_{5}$ と $\mathrm{SiO}_{2}$ のものよりも遙かに大きい. このことから，この波長のレーザを $\mathrm{BM}$ 上の $\mathrm{Bi}: \mathrm{YIG}$ に照射すると, $\mathrm{Ta}_{2} \mathrm{O}_{5}$ 層は光を吸収せず, $\mathrm{Bi}: \mathrm{YIG}$

(a)

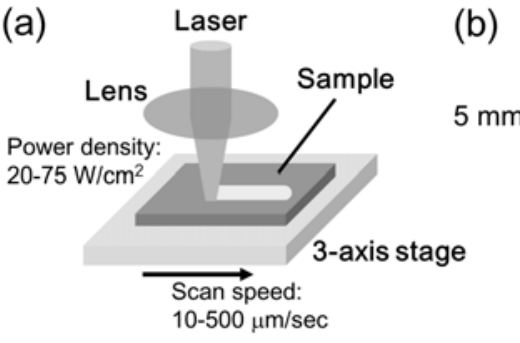

(b)

Fig. 2 (a) Sketch of laser-annealing system. (b) Optical microscopic surface image of the sample annealed by laser. The gray area (0.6 $\mathrm{mm}$ width line) was annealed by laser-annealing system. 
だけが選択的に光を吸収し，加熱され，結晶化すると期待できる.

本稿では, 最初に合成石英基板上にて Bi:YIG を形成可能なレ一 ザ熱処理条件について述べる. 次に当該条件を用いた $\mathrm{BM}$ 上の Bi:YIG の形成方法, 及び試料の評価結果について述べる.

\section{2. 実験方法}

\section{1 レーザを用いた Bi:YIG の熱処理方法}

大きなファラデー回転角を有する $\mathrm{Bi}: \mathrm{YIG}$ 薄膜が得られるレー ザ熱処理条件を探査した. $\mathrm{Bi}_{1.0} \mathrm{Y}_{2.5} \mathrm{Fe}_{5} \mathrm{O}_{\mathrm{x}}$ の焼結体ターゲットを用 いて，高周波マグネトロンスパッタ法により厚さ $1.0 \mu \mathrm{m}$ の膜を合 成石英基板上に堆積寸ることで試料を形成した. 成膜は投入電力 $100 \mathrm{~W}, 10$ mTorr $の \mathrm{Ar}$ ガス雰井気中で行い，基板温度は室温と した. 堆積した膜は非晶質であり，大気中でレーザ光を照射する ことによって結晶化させた. 試料構造は Glass substrate/Bi:YIG と記述できる.

Figure 2 にレーザ熱処理装置の概略図を示寸. 装置には発振波 長 $532 \mathrm{~nm}$, 出力 $320 \mathrm{~mW}, \mathrm{CW}$ 発振のレーザ (Coherent, Verdi-2W）を用いた. レーザの強度分布は，ガウシアン分布であ った. レーザ光の試料表面でのパワー密度 $p$ はスポットサイズを 変化することで, $27 \sim 136 \mathrm{~W} / \mathrm{cm}^{2}$ の範囲で調節した. スポットサ イズはレンズと試料間距離を変化させて $300 ６ 00 \mu \mathrm{m}$ の範囲で 変化させた. 試料は 3 軸の自動ステージ上に固定し, レーザ光を 照射しながら走査速度 $s d=10 \sim 500 \mu \mathrm{m} / \mathrm{s}$ で走査し，ライン状に 結晶化熱処理を行った.

試料の評価は，X 線回折装置（RINT2500，Cu-Ka線源）によ る結晶構造の同定, 回転検光子法を用いた波長可変型磁気光学特 性測定装置（Neo Ark, BHM600VIR-FKR-TU）によるファラデ 一回転角の測定を行った. 比較の為に電気炉熱処理により結晶化 させた Bi:YIG 薄膜のファラデー回転角の大きさも測定した. 電気 炉熱処理の条件は, 温度 $500 \sim 1000{ }^{\circ} \mathrm{C}$ で 20 分間とし, 大気中で 行った.

\section{2 誘電体ミラー上の $\mathrm{Bi}: \mathrm{YIG}$ の選択的熱処理方法}

厚さ $0.7 \mathrm{~mm}$ の $\mathrm{SGGG}\left((\mathrm{GdCa})_{3}(\mathrm{GaMgZr})_{5} \mathrm{O}_{12}\right)$ 基板上に 4 ペ アの $\mathrm{Ta}_{2} \mathrm{O}_{5}$ 層と $\mathrm{SiO}_{2}$ 層からなる誘電体ミラー $\left(\mathrm{Ta}_{2} \mathrm{O}_{5} / \mathrm{SiO}_{2}\right)^{4}$ を電 子ビーム蒸着法によって形成し, その上に高周波マグネトロンス パッタ法により $\mathrm{Bi}: \mathrm{YIG}$ 薄膜を形成した. $\mathrm{Ta}_{2} \mathrm{O}_{5}, \mathrm{SiO}_{2}, \mathrm{Bi}: \mathrm{YIG}$ の膜厚はそれぞれ，59, 90, $870 \mathrm{~nm}$ であった. 試料構造はSGGG substrate/( $\left.\mathrm{Ta}_{2} \mathrm{O}_{5} / \mathrm{SiO}_{2}\right)^{4} / \mathrm{Bi}: \mathrm{YIG}$ と記述できる. 当該試料の Bi:YIG 層を電気炉熱処理とレーザ熱処理を用いて結晶化させた. 電気炉 熱処理は $750{ }^{\circ} \mathrm{C}$ で 20 分間行い, レーザ熱処理はパワー密度 $p=$ $101 \mathrm{~W} / \mathrm{cm}^{2}$, 走查速度 $s d=40 \mu \mathrm{m} / \mathrm{s}$ で行った.

試料の評価は, 光学顕微鏡による表面観察, 試料各層の断面 $\mathrm{TEM}$ 像と電子回折パターンの撮影, レーザ磁気光学顕微鏡 ${ }^{177}$ を用 いたカー回転角の測定を行った。

\section{3. 実験結果}

\section{1 レーザを用いた Bi:YIG の熱処理の結果}

Figure 3 に，レーザの走査速度 $s d を$ 変化してレーサ熱処理した 試料Glass substrate/Bi:YIG のファラデー回転角を示す。このと

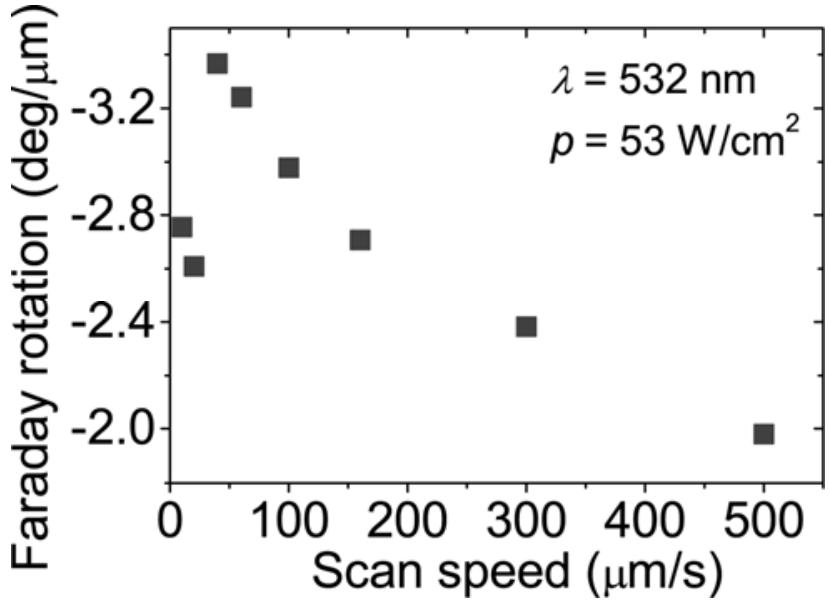

Fig. 3 Faraday rotation angle at wavelength $\lambda=532$ $\mathrm{nm}$ of samples -Glass substrate/Bi:YIG- annealed by laser with several scan speed $s d$. Power density $p$ was $53 \mathrm{~W} / \mathrm{cm}^{2}$.

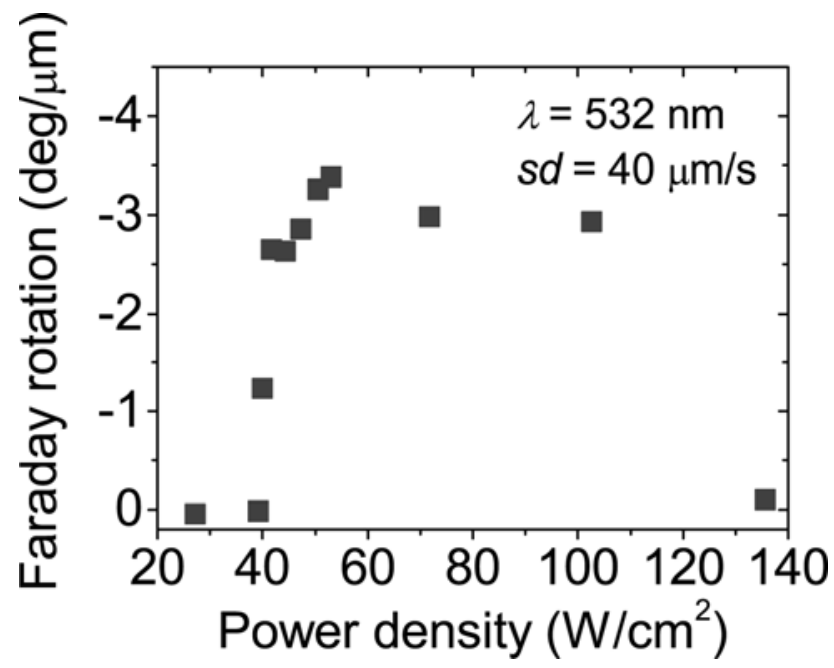

Fig. 4 Faraday rotation angle at wavelength $\lambda=532$ $\mathrm{nm}$ of samples -Glass substrate/Bi:YIG- annealed by laser with several power density $p$. Scan speed $s d$ was $40 \mu \mathrm{m} / \mathrm{s}$.

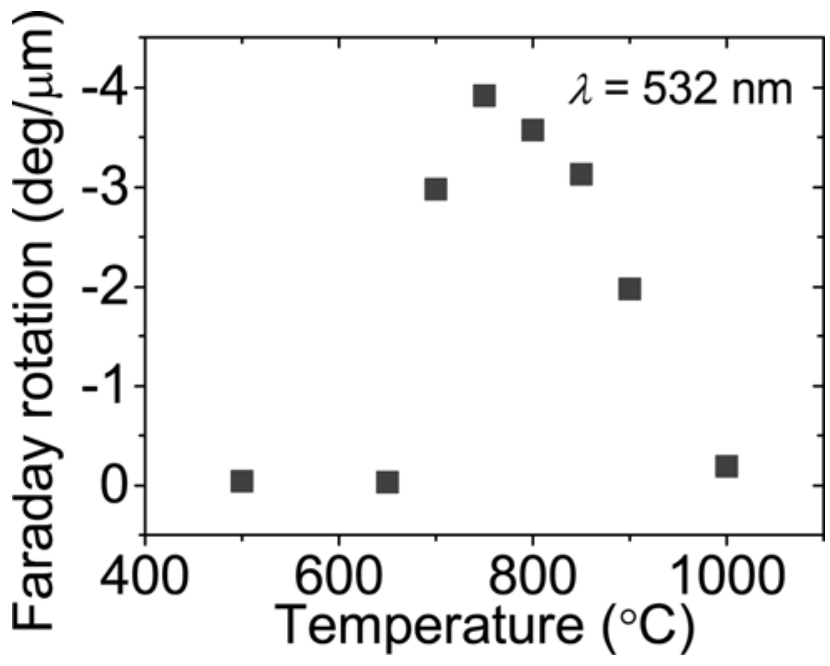

Fig. 5 Faraday rotation angel at wavelength $\lambda=532$ $\mathrm{nm}$ of samples -Glass substrate/Bi:YIG- annealed by electric furnace at several temperature for 20 minutes. 


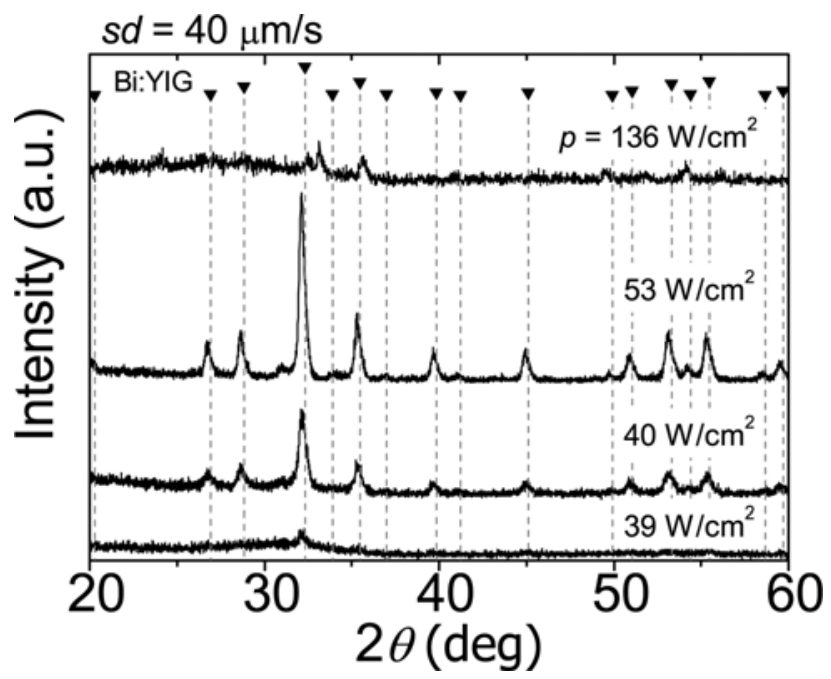

Fig. 6 XRD patterns of samples -Glass substrate/Bi:YIGannealed by laser with several power density $p$. Scan speed sd was $40 \mu \mathrm{m} / \mathrm{s}$. The triangles show the powder diffraction pattern of Bi:YIG.

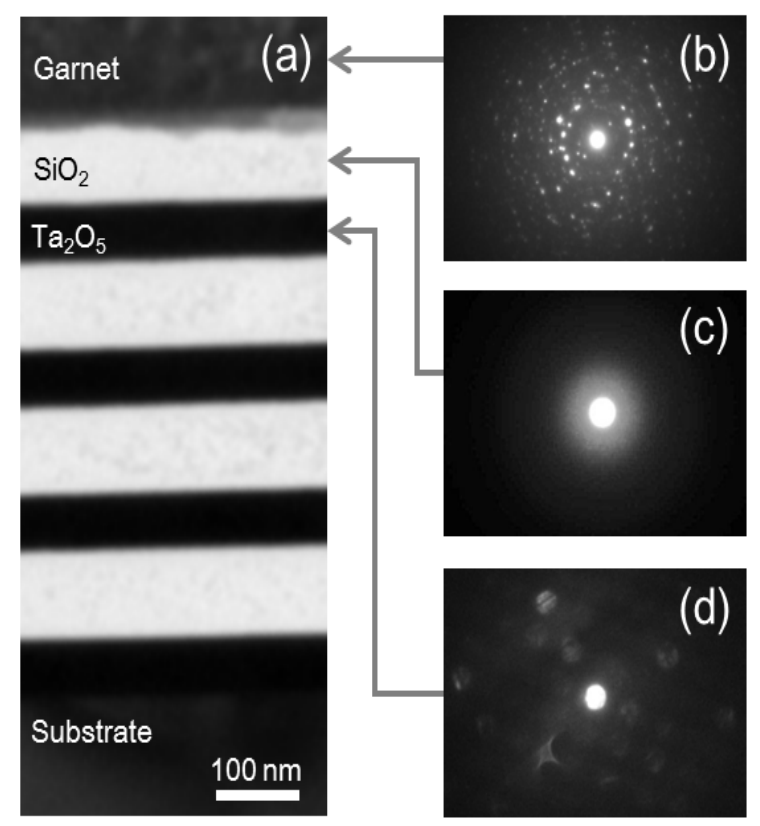

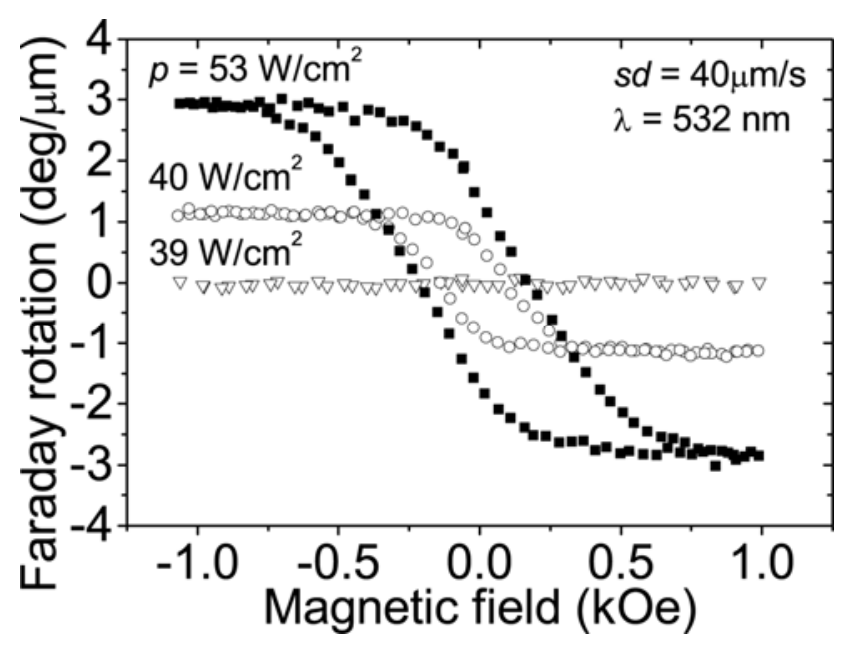

Fig. 7 Faraday rotation loop versus applied field of samples -Glass substrate/Bi:YIG-. The magnetic field was applied to films perpendicularly.

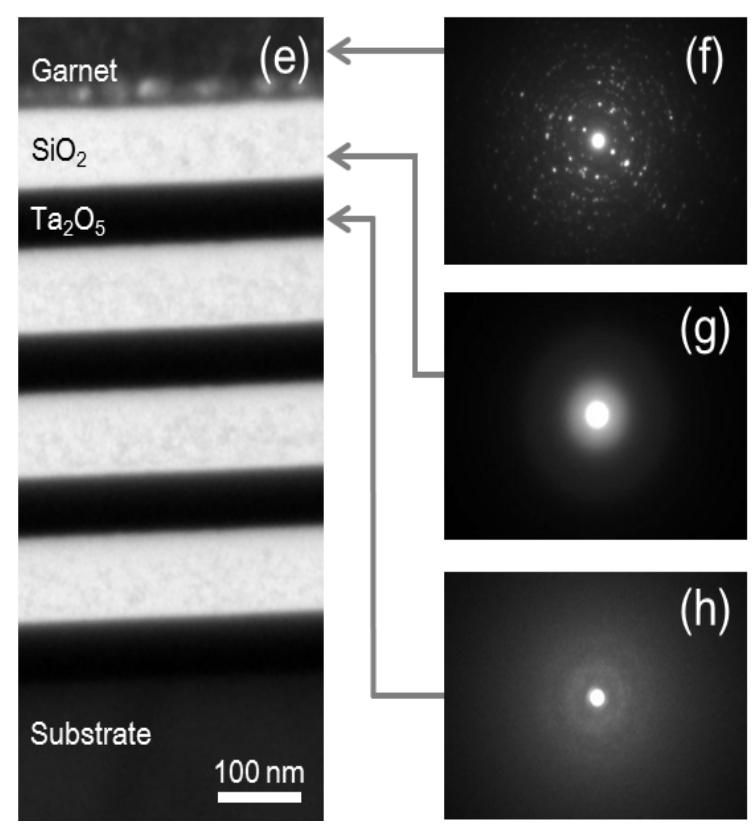

Fig. 8 Cross-sectional TEM images of samples $-\mathrm{SGGG}$ substrate/(Ta2 $\left.\mathrm{O}_{5} / \mathrm{SiO}_{2}\right)^{4} / \mathrm{Bi}: \mathrm{YIG}-$ annealed by electric furnace $\left(750{ }^{\circ} \mathrm{C}, 20\right.$ minutes) (a), and laser $\left(s d=40 \mu \mathrm{m} / \mathrm{s}, p=101 \mathrm{~W} / \mathrm{cm}^{2}\right)$ (e). The electron diffraction patterns of each layers are shown in $(b),(c),(d),(f),(g)$ and $(h)$.

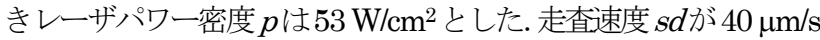
のとき最も大きなファラデー回転角 $-3.4 \mathrm{deg} / \mu \mathrm{m}$ を示した. このと きの走査速度 $s d=40 \mu \mathrm{m} / \mathrm{s}$ を用いて，レーザパワー密度 $p$ を変化 してレーザ熱処理した試料のファラデー回転角を測定した (Figure 4). パワー密度 $40 \sim 100 \mathrm{~W} / \mathrm{cm}^{2}$ のとき-2.7 -3.3 $\mathrm{deg} / \mu \mathrm{m}$ の比較的大きなファラデー回転角が得られた. これは, 同 構造をもつ試料を電気炉熱処理したときと同程度の值 (Figure 5) であり，レーザ熱処理で Bi:YIG を形成可能であることを示してい る. 実際に, レーザ熱処理した試料の X 線回折パターン (Figure 6) を見ると, レーザのパワー密度 $p$ が $39 \mathrm{~W} / \mathrm{cm}^{2}$ のときは回折ピーク が見られず非晶質であるのに対し，パワー密度が $40,53 \mathrm{~W} / \mathrm{cm}^{2}$ の
ときは結晶化していることが分かる.

一方，パワー密度が $136 \mathrm{~W} / \mathrm{cm}^{2}$ と大きい場合は，試料は結晶化 していない. このことから, Figure 3, 4 において, 走査速度が遅 すぎるか, パワー密度が大きすぎた場合にファラデー回転角が減 少しているのは, 試料が，ガーネット相が安定な温度以上に加熱 され，ガーネット構造が得られなかった為と考えられる.

Figure 7 からレーザ熱処理した Bi:YIG は, 飽和磁界約 1 kOe の強磁性特性をもつことが分かる. これは電気炉熱処理を用いて 形成したガーネット薄膜の, 多結晶粒が磁気的に僅かに結合した モデルが示す, 保磁力と共にファラデー回転角が増加する磁化過 程 ${ }^{18)}$ とよく一致する. 

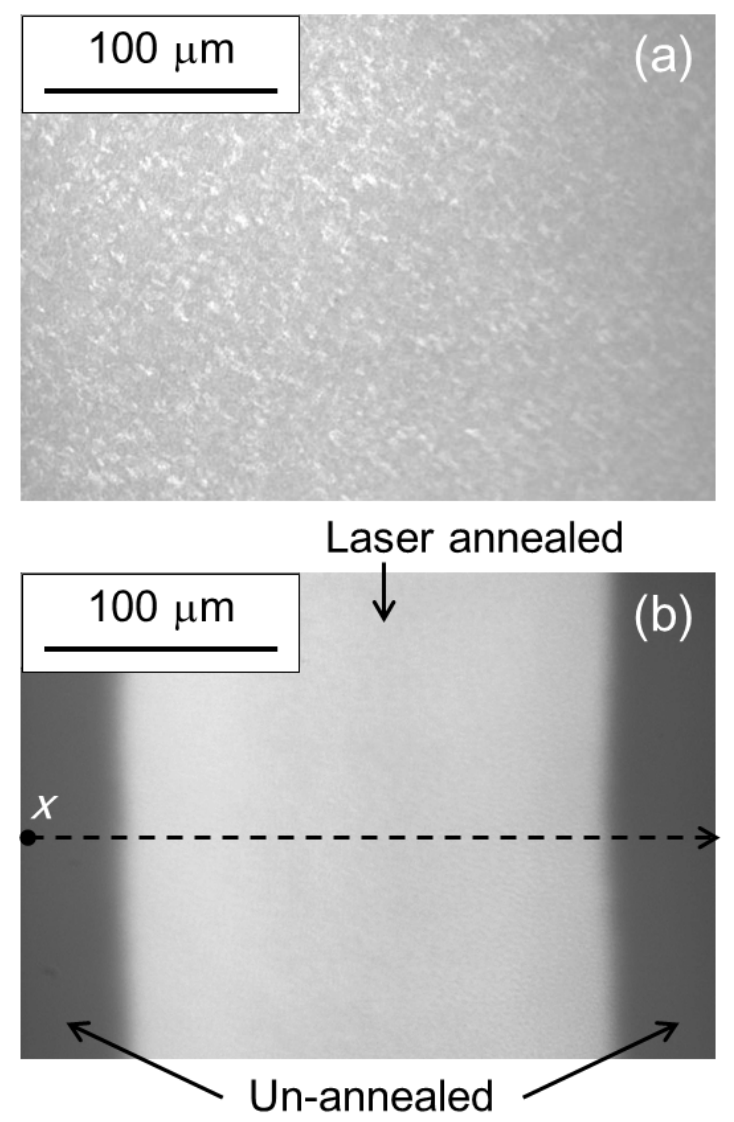

Fig. 9 Optical microscopic surface images of samples SGGG substrate/( $\left.\mathrm{Ta}_{2} \mathrm{O}_{5} / \mathrm{SiO}_{2}\right)^{4} / \mathrm{Bi}: \mathrm{YIG}-$ annealed by electric furnace $\left(750{ }^{\circ} \mathrm{C}, 20\right.$ minutes) (a) and laser ( $s d=$ $\left.40 \mu \mathrm{m} / \mathrm{s}, p=101 \mathrm{~W} / \mathrm{cm}^{2}\right)(\mathrm{b})$.

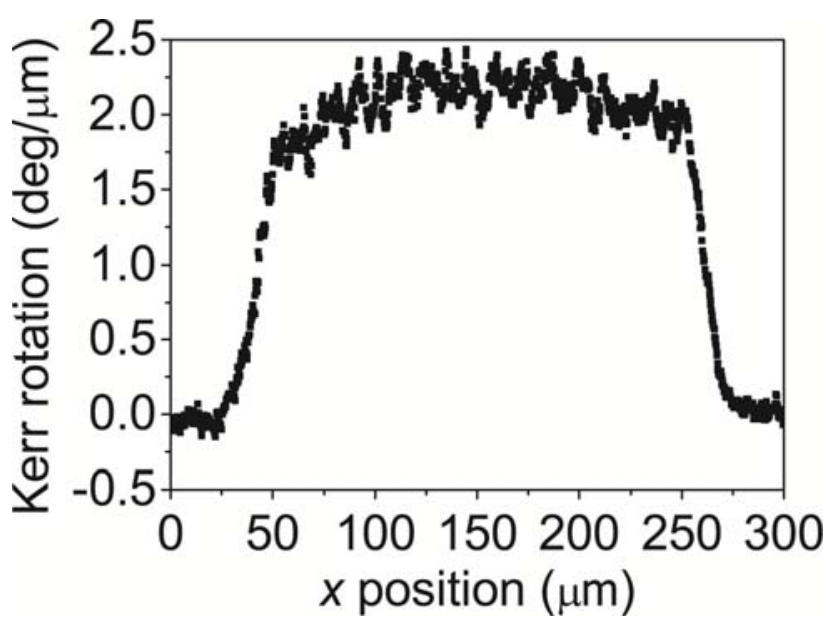

Fig. 10 In-plane distribution of Kerr rotation angle of the sample -SGGG substrate/( $\left.\mathrm{Ta}_{2} \mathrm{O}_{5} / \mathrm{SiO}_{2}\right)^{4} / \mathrm{Bi}$ :YIGannealed by laser $\left(s d=40 \mu \mathrm{m} / \mathrm{s}, p=101 \mathrm{~W} / \mathrm{cm}^{2}\right)$.

合成石英基板上の $\mathrm{Bi}: \mathrm{YIG}$ は，走査速度 $s d$ が $40 \mu \mathrm{m} / \mathrm{s}$ ，パワー 密度 $p$ が $40 \sim 100 \mathrm{~W} / \mathrm{cm}^{2}$ のレーサ熱処理によって結晶化し, 電 気炉熱処理を用いた時と同程度のファラデー回転角を示した．以 上より，レーザ熱処理を用いても電気炉熱処理を用いた時と同程 度の MO 効果を有する Bi:YIG が形成可能であることが分かった.

\section{2 誘電体ミラー上の $\mathrm{Bi}: \mathrm{YIG}$ の選択的熱処理の結果}

Figure 8 に, 電気炉とレーザで熱処理した試料 SGGG substrate $/\left(\mathrm{Ta}_{2} \mathrm{O}_{5} / \mathrm{SiO}_{2}\right)^{4} / \mathrm{Bi}$ :YIG の断面 TEM 像と各層の電子線回 折パターンを示寸. 電気炉熱処理した試料の $\mathrm{Bi}: \mathrm{YIG}$ 層と $\mathrm{Ta}_{2} \mathrm{O}_{5}$ 層では回折点が見られ，これらの層が熱処理によって結晶化して いることが分かる。一方で，レーザ熱処理した試料は Bi:YIG 層だ けが回折点を示し, $\mathrm{Ta}_{2} \mathrm{O}_{5}$ 層は八ローを示し, 非晶質であることが 分かる. 熱処理後の試料の波長 $532 \mathrm{~nm}$ におけるファラデー回転

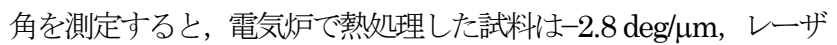

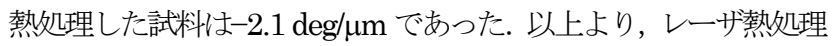
を用いることで $\mathrm{BM}$ 中の $\mathrm{Ta}_{2} \mathrm{O}_{5}$ を結晶化させることなく, $\mathrm{BM}$ 上 の Bi:YIG を選択的に結晶化できたと考えられる.

レーザ熱処理を用いた時には，BM 中の $\mathrm{Ta}_{2} \mathrm{O}_{5}$ が結晶化してい ないことから, 光散乱が抑えられていると考えられる. この点を 確認する目的で，光学顕微鏡で熱処理後の試料表面を観察した

(Figure 9). 膜面から光を入射し，反射光を CCD カメラによっ て撮影した．電気炉熱処理した試料では $\mathrm{Ta}_{2} \mathrm{O}_{5}$ の結晶化による光 散乱（Fig. 9 (a)中の白い斑点）が見られるが，レーザで熱処理し た試料のレーザ照射を行った部分（Fig. 9 (b)中の白い带状領域） では見られない，レーザ熱処理を用いることで，下部 BM 中の $\mathrm{Ta}_{2} \mathrm{O}_{5}$ の結晶化に伴う光散乱の発生が抑えられたと考えられる.

ここで, Figure 9 (b)中のレーザ熱処理した部分としていない部 分の境界が明瞭でないことが認められる.これは，レーザの面内 の強度分布がガウシアン分布をしており，膜の面内方向に温度分 布が生じ，Bi:YIGの粒径，及び結晶性に分布が生じた為と考えら れる. 実際に, 反射型のレーザ磁気光学顕微鏡を用いて, Figure 9 (b)中に示したx 軸に沿って, カ一回転角を測定した(Figure 10). 試料のレーザ熱処理した部分としていない部分の境界に勾配が見 られることから温度分布によって粒成長の様子が変化していると 考えられる. 今後, 有限要素法を用いてレーザ熱処理時の膜内温 度分布, 粒成長の様子, 及び MO 効果に与える影響を詳しく解析 する予定である.

\section{4. まとめ}

MPC を構成する材料のうち Bi:YIG だけが光吸収する波長 532 $\mathrm{nm}$ の連続発振レーザを用いて, BM 上の Bi:YIG 薄膜の選択的結 晶化熱処理を行った. 以下の結果を得た.

（1）合成石英基板上に厚さ $1.0 \mu \mathrm{m}$ の $\mathrm{Bi}: \mathrm{YIG}$ 薄膜を堆積した 試料にて，レーザ熱処理条件を探査した. その結果，走査 速度 $40 \mu \mathrm{m} / \mathrm{s}$ ，パワー密度 $40 \sim 100 \mathrm{~W} / \mathrm{cm}^{2}$ でレーザ熱処 理することで試料は結晶化し，電気炉熱処理を用いた時と 同程度のファラデー回転角を示すことが分かった。

（2） BM上のBi:YIG薄膜のレーザ熱処理を行った. その結果， $\mathrm{BM}$ 中の $\mathrm{Ta}_{2} \mathrm{O}_{5}$ は熱処理後も結晶化せず，且つ， $\mathrm{BM}$ 上の $\mathrm{Bi}: Y I G$ 膜は電気炉熱処理を用いた時と同程度のファラデ 一回転角を示すことが分かった。

本稿の実験結果は，レーザ熱処理を用いて下部 $\mathrm{BM}$ 中の $\mathrm{Ta}_{2} \mathrm{O}_{5}$ の結晶化による散乱損失を伴わずに MPC が形成可能であること を示すものといえる. 今後は，レーザ熱処理を用いた MPC，及び 


\section{MOSLM の作製を行う予定である。}

\section{References}

1) M. Inoue, R. Fujikawa, A. V. Baryshev, A. Khanikaev, P. B. Lim, H. Uchida, O. Aktsipetrov, A. Fedyanin, T. Murzina and A. Granovsky: J. Phys. D, 39, R151 (2006).

2) T. Goto, H. Sato, A. Kume, H. Takagi and M. Inoue: J. Appl. Phys., 109, (2011).

3) W. E. Ross, D. Psaltis and R. H. Anderson: Opt. Eng., 22, 485 (1983).

4) A. M. Grishin and S. I. Khartsev: J. Magn. Soc. Jpn., 32, 140 (2008).

5) A. M. Merzlikin, A. P. Vinogradov, A. V. Dorofeenko, M. Inoue, M. Levy and A. B. Granovsky: Physica B, 394, 277 (2007).

6) M. Inoue, K. Arai, T. Fujii and M. Abe: J. Appl. Phys., 83, 6768 (1998).

7) T. Goto and M. Inoue: J. Appl. Phys., 111, 07 A913 (2012).

8) Y. Haga, T. Goto, A. V. Baryshev and M. Inoue: J. Magn. Soc. Jpn., 36, 54 (2012).
9) S. Wittekoek, T. J. A. Popma, J. M. Robertson and P. F. Bongers: Phys. Rev. B, 12, 2777 (1975).

10) S. Wittekoek and T. J. A. Popma: J. Appl. Phys., 44, 5560 (1973).

11) S. Kahl, S. I. Khartsev, A. M. Grishin, K. Kawano, G. Kong, R. A. Chakalov and J. S. Abell: J. Appl. Phys., 91, 9556 (2002).

12) T. Ishibashi, A. Mizusawa, M. Nagai, S. Shimizu and K. Sato: J. Appl. Phys., 97, 013516 (2005).

13) T. Goto, A. V. Dorofeenko, A. M. Merzlikin, A. V. Baryshev, A. P. Vinogradov, M. Inoue, A. A. Lisyansky and A. B. Granovsky: Phys. Rev. Lett., 101, 113902 (2008).

14) T. Ishibashi, T. Kawata, T. H. Johansen, J. He, N. Harada and K. Sato: J. Magn. Soc. Jpn., 32, 150 (2008).

15) T. Goto, A. V. Baryshev, K. Tobinaga and M. Inoue: J. Appl. Phys., 107, 09A946 (2010).

16) H. Takagi, J. Kim, K. H. Chung, S. Mito, H. Umezawa and M. Inoue: J. Magn. Soc. Jpn., 33, 525 (2009).

17) T. Mano, S. Mito, T. Kato, H. Takagi, J. Kim, P. B. Lim, B. Alexander and M. Inoue: Trans. Inst. Electr. Eng. Jpn. A, 130, 636 (2010).

18) S. Mito, H. Sakurai, H. Takagi, A. V. Baryshev and M. Inoue: J. Appl. Phys., 111, 07A519 (2012).

2011年11月3日受理，2012年3月6日再受理，2012年3月16日採録 